The impact of the rapid growth of the electronic industry on the company, both organizationally and technically, forms the major part of the discussion in the third section.

Throughout the text the author has taken pains to relate the developments in technology to the overall philosophy of the firm which Marconi started and gives much detailed information on the individuals responsible for the successive transformations which the company underwent. In his summary the author concludes that the company has flourished during the seventy year period largely because of "top quality in engineering craftsmanship and materials; a thorough training of youth for the future and a generous feedback of profits into rescarch and development".

It is to be hoped that this work will stimulate other historians to undertake the essential task of compiling contemporary industrial histories which alone can provide the basis of more analytical work on the relationship between technology and industry. Michael Gibbons

\section{PRAGMATIC ECONOMIST}

Papers on Planning and Economic Management By Ely Devons. Edited by Alec Cairncross. Pp. vii +278 . (Manchester University: Manchester, September 1970.) $60 s$.

Ely Devoys was not one of the leading theorists of his generation. Reared in the traditional political economy mould of the University of Manchester he bore the stamp of that institution throughout his career. Fver sceptical of high-flown theories and acutely aware of the dangers that arise from divorcing fact and theory, Devons was, by his very nature, a pragmatic man ready to see issues at their face value and anxious to analyse problems simply but positively. He was probably too wide-ranging in his thoughts and writings ever to be a leading theorist, and in any case he was happy to let the facts speak for themselves rather than to devise hypotheses or theories about what might happen outside reality. He was also too busy teaching and looking after successive intakes of students to have much time left for intensive research.

To his students (and I number one of them) Devons had an acute intellect which could cut through any prob. lem incisively and which could also, much to the chagrin of those concerned, quickly detect the weakness of his opponents' arguments. He was sparing of words but what he had to say was expressed with great clarity. In general Devons was not content to specialize exclusively on one small area of study, though he will be best remembered for his books on planning and economic statistics. He preferred, however, to operate on a wider plane often at the frontiers where different disciplines met. Much of the time he spent debating general issues relating to economic management, planning, administration, and, later, university affairs, and the essays in this volume (introduced with a memoir by Professor Cairncross) reflect his interests in these matters. Many readers may regard them as rather lightweight, and it must be admitted that one or two of them, especially the reviews of books, might have been left out. Nevertheless, they are nearly all worth reading again, for they show Devons's sharp grasp of essentials, his ability to analyse problems clearly, his deliberate attempt to question accepted notions and, above all, the self-critical expression of his own profession. In this last respect Devons (perhaps with tongue in cheek occasionally) was at his best, and economics and economists often came in for some hard knocks. For example, he noted the pitiful way underdeveloped countries have been bombarded with successive theories of development receiving, as they do, "ever-changing diagnosis and advice from the peripatetic group of economists tripping from one to the other giving them the benefit of the latest advances in the so-called theories of economic growth and economic development. In all this there seems to be a recklessness in putting forward newly formulated but untried theories as guides to policy".

The general roader in particular will find these essays to his liking. They cover issues of topical interest, they are elegantly written and free from professional jargon and they are spiced with sarcastic wit.

Derex H. Aldcroft

\section{PLEISTOCENE TOPICS}

\section{Ice Ages}

Their Nature and Effects. By Ian Cornwall. Pp. 180. (John Baker: London; Humanities: New York, July 1970.) $63 \mathrm{~s}$.

THIs book, somewhat expensive for its length and style, takes a general view of the Pleistocene ice ages. It is written for students of the natural sciences and of archaeology and for the general reader-certainly a wide field of readership. It is really an introduction to the subject and deals in an elementary fashion with the many facets of studies relating to ice ages and their changing environments-geological, geographical, biological and arehaeological.

Such an introduction has a very useful part to play, especially now that environmental studies of past and present are becoming, quite rightly, more and more p spular. How far does this book satisfy the requirements of an introductory text? It is certainly written in a readable style, the figures are clear and most of the plates provide helpful illustrations. But the reader is entitled to expect correct information and an up to date approach to the subject, and criticism can be made of this book on both these scores. A single example of the former will suffice: many of the distributions of plants given in the section on Pleistocene floras are incorrect.

A more important criticism is that the approach to parts of the subject is antiquated. In the section on Pleistocene fauna, we are told only of mammals, in spite of the great interest of recent work on molluses and beetles, both of which groups are very revealing in interpreting past environments. Moreover, the account of the mammal fauna is clearly based on Zeuner's 1945 lists, and much has happened to our knowledge of Pleistocene faunas and chronology since then. Another criticism concerns the absence of any clear definitions of terms used in defining climatic periods. In the absence of such clear definitions, the author perpetuates ideas current in Pleistocene chronology some thirty years ago. Thus the idea that Penck and Brückner's classification of the Alpine sequence can be used as a stratigraphic basis for the rest of Europe is not questioned or considered. As a result, the alpine terms and the torm "great interglacial" are liberally used in reference to areas beyond the Alps; it has yet to be proved that a "great" interglacial exists in north-west Europe. These difficulties partly stem from lack of definitions. Nevertheless, to the beginner in the subject it should bo made quite clear that correlation of major ice advances and interglacials in the Alps, northern Europe and Britain is a subject of great difficulty, and that there is still no clearly accepted scheme of cold and temperate periods which brings these three areas together chronologically.

Another difficulty for the reader stems from the acceptance of Milankovitch's radiation curve (described as a method of absolute dating) as a basis for stratigraphic correlation. What is really required is a discussion of the stratigraphical evidence for the hypothesis that the course of the curve is related to geological events.

Apart from these considerations, the book has a reasonable coverage of Pleistocene topics. But it is unfortunate that the chronological and stratigraphical framework lacks a modern perspective, and a good opportunity for the presentation of the position in Pleistocone studies today has been lost.
R. G. WEST 